\title{
ВЫМЫСЕЛ КАК ЛОЖЬ И ФАНТАЗИЯ ВО ФРАЗЕОЛОГИИ АНГЛИЙСКОГО И РУССКОГО ЯЗЫКОВ
}

Федюніна I. Е. Вимисел як обман та фантазія у фразеології англійської і російської мов.

У статті розглядаються семантика, внутрішня форма та специфіка іллокутивного ефекту російських і англійських фразеологічних одиниць із загальним значенням «Вигадка». Виявляються закономірності оцінної категоризації вимислу як феномена спілкування носіями російської й англійської лінгвокультур.

Ключові слова: фразеологізм, вимисел, іллокутивний ефект, флуктуація, кореляція, категоризація, дискурсивна залежність.

Федюнина И. Э. Вымысел как ложь и фантазия во фразеологии английского и русского языков

В статье рассматриваются семантика, внутренняя форма и специфика иллокутивного эффекта русских и английских фразеологических единиц с общим 
значением «Вымысел». Выявляются закономерности оценочной категоризации вымысла как феномена общения носителями русской и английской лингвокультур.

Ключевые слова: фразеологизм, вымысел, иллокутивный эффект, флуктуация, корреляция, категоризация, дискурсивная зависимость.

Fedyunina I. E. Fiction as a lie and the fruit of imagination represented by English and Russian idioms

The article deals with semantics, inner form and pragmatic impact of Russian and English idioms with the general meaning of fiction. The author reveals the common factors affecting the attitudes of Russian and English native speakers to phenomenon towards fiction in everyday communication.

Key words: idiom, fiction, pragmatic impact, fluctuation, correlation, categorization, discourse functioning.

Сегодня фразеологические единицы (ФЕ) активно изучаются в самых разных аспектах. Одним из наиболее продуктивных и перспективных направлений современной фразеологии представляется когнитивно-прагматический подход [2;9; 17], в рамках которого исследуется одно из самых ценных, на наш взгляд, свойств ФЕ - их способность производить иллокутивный, или прагматический, эффект, то есть вызывать у реципиента высказывания то или иное чувство-отношение к человеку, поступку или ситуации, характеризуемым посредством ФЕ.

Исследование закономерностей фразеологической объективации вымысла как феномена психики и коммуникации представляет немалый интерес в силу двойственности его восприятия и категоризации. Эта двойственность отражена уже в самих словарных дефинициях понятия «вымысел» и является универсальной для обоих исследуемых языков - русского (РЯ) и английского (АЯ). В толковых словарях РЯ вымысел определяется двояко: с одной стороны как «то, что создано воображением, фантазией, выдумка» и «ложное, ошибочное представление о чём-то, не соответствующее действительности», с другой - как «заведомая ложь, измышление» [4, с. 263]. В АЯ соответствующие лексемы имеют сходные определения. Таким образом, даже из содержания нейтральных единиц очевидна двойственность категоризации вымысла как в формально-логическом, так и в оценочном планах. Анализ специализированной литературы подтверждает этот факт. Многие лингвисты и психологи, работающие в области психологии обмана, приравнивают вымысел к дезинформации (или фальсификации), считая, что и то и другое - «две различных техники достижения одной и той же цели - сознательного введения в заблуждение» 
[15, с. 334]. Вместе с тем вымысел, даже будучи определён как обман, выделяется исследователями в особую его форму - т. н. «прозрачный обман» (коммуникативная ситуация, имеющая вид своеобразной игры, в которой о факте дезинформации и истинном положении дел осведомлены оба участника, но адресат по тем или иным причинам не уличает обманщика) [11]. Специалисты также признают, что субъект, измышляющий нечто не соответствующее действительности, не всегда имеет неблаговидные цели или корыстные намерения. Вымысел как когнитивная деятельность в большой степени является результатом и показателем креативности мышления, а также ответом на психологическую потребность человека в приукрашивании действительности в тех ситуациях, когда он не удовлетворён реальным положением дел, будь то в прошлом или в настоящем, но не имеет возможности его изменить. В этом аспекте вымысел не только востребован, но и зачастую необходим для психологического комфорта, повышения самооценки и сохранения позитивного отношения к жизни.

Согласно одному из основных принципов когнитивной фразеологии, актуальное значение ФЕ «формируется на основании знаний о мире, фиксированных в когнитивной системе в виде концептов» [2, с. 240], причём концепты в системе тесно взаимосвязаны. Поэтому всякое явление, становящееся объектом категоризации, коррелирует с теми или иными концептами, позитивными или негативными, уже имеющимися в концептуальной системе носителя языка. При этом важную роль играет особый вид категоризации - оценочная категоризация, «результат интеракции двух концептуальных систем - той, что имеет происхождение из физического мира и той, что производна от человеческой системы ценностей» $[12$, с. 5]. Эта модель категоризации релятивна, то есть функционирует относительно исходной («логической») модели и может принимать разные формы «сосуществования» с ней - от полной согласованности до полного игнорирования; последнее может вызвать смещение категориальных границ репрезентации объекта. На языковом уровне эта тенденция реализуется при взаимодействии ФЕ с контекстом благодаря ситуативности оценки и, как следствие, гибкости значения, в результате чего контекст может актуализировать определённые стороны семантики ФЕ и создавать смысловые изменения. Это свойство ФЕ называется контекстуальной сензитивностью, или дискурсивной зависимостью. Таким образом, одна и та же ФЕ, функционируя в контекстах, может «отсылать» к 
разным в оценочном плане концептам. В этом плане изучение ФЕ с семантикой вымысла на межъязыковом материале видится особенно интересным, так как оценочная категоризация во многом определяется личностными особенностями носителя языка и социокультурными нормами общества, к которому он принадлежит: «субъективнокультурный фактор определяет... категоризацию объекта, выбор ономасиологического основания номинации и признаков объекта, актуализируемых в конкретном высказывании» [17, с. 117].

Перейдем к рассмотрению фразеологических репрезентаций феномена вымысла. Образные представления о вымысле объективируются сравнительно небольшой группой ФЕ, объединённых семантическим инвариантом «рассказывать нечто явно не соответствующее действительности»: рассказывать охотничьи / солдатские / моряцкие басни, травить байки (РЯ), to tell cock-and-bull stories / traveller's tales, to spin a yarn (АЯ) и др. Вымысел репрезентируется как идиомами, так и фразеологическими сочетаниями (коллокациями). Коллокации характеризуются широкой структурной, лексической и грамматической вариативностью. Они могут функционировать как в полном составе, так и в стяжённой форме. Второй компонент коллокаций (сказки, tales) чётко отражает особенность, о которой говорилось выше: коммуникативная ситуация вымысла представляет собой прозрачный обман. Поэтому ФЕ изначально несут семы ироничности, снисходительности, пренебрежения, насмешки. Важным фактором иллокутивного эффекта ФЕ данного ряда представляется также их внутренняя форма, реализуемая компонентами охотничьи, моряцкие, traveller's и т. п. Стереотипный образ, лежащий в их основе, даёт ассоциацию с пребыванием субъекта в неких экстремальных ситуациях, опасных и вместе с тем притягательных, необычных, недоступных для большинства слушателей в повседневной жизни и потому несущих чрезвычайно привлекательную для них информацию. Эта информация, с одной стороны, интересна и вносит разнообразие в их жизнь, с другой - наверняка во многом не соответствует действительности, но последнее не имеет решающего значения, если не причиняет никому вреда. Кроме того, двойственность семантики обусловливает флуктуацию оценки данных ФЕ и высокую степень контекстуальной сензитивности. Проиллюстрируем это с помощью четырёх групп примеров.

(1) Kalenberg's face got red, distorted with fury. "You dare to come here and tell me tales! Tresspassers! You Il pay for it!” [13, c. 124]. B 
этой ситуации ФЕ несет резко негативную коннотацию; очевидна корреляция с концептом «Опасность», а вымышленная история квалифицируется как злостная дезинформация, имеющая целью навредить реципиенту, оскорбляющая его (концепт «Унижение») и вызывающая, соответственно, гнев и ярость. ... заснуть он не мог, ... думал: «Зачем я им нужен? Рассказы о долгах и честном дележе небрежно сложснная сказка. Зачем я им нужен?» [6, с. 64]. Здесь также очевидно сближение вымысла с дезинформацией, а незнание истинных целей субъекта внушает реципиенту дискомфорт и страх (связь с концептами «Опасность», «Вред»). “...you'll excuse me, Mr Poirot - you are an ingenious man. You could cook up a tale”. Poirot drew himself up. "I may be, mon cher, an artistic and competent liar... But it is not my idea of ethical conduct" [14, c. 32]. Этот контекст интересен лингвистически эксплицированным столкновением двух корреляций вымысла - признания высокого мастерства субъекта в данной сфере (концепт «Искусство») и квалификации подобного поведения как неприемлемого с позиции нравственности. При этом решающим фактором конечной негативной оценки действия выступает ценностная ориентация говорящего. В целом все контексты первой группы объединяет актуализация негативных признаков вымысла, бесчестных намерений субъекта и их вредоносных последствий, что обеспечивает логическую категоризацию вымысла как дезинформации.

(2) Даже мальчишки перестали верить моряцким басням о бутылках, залитых воском и выброшенных на пески прибоем; Андреев чертыхнулся... и объявил, что ему смертельно надоели эти охотничьи басни [5, с. 245]; “I don't need those fairy tales of yours! He is seriously ill, isn't he?" [14, c. 152]. В контекстах этой группы не наблюдается явного отнесения вымысла к категории дезинформации, равно как и актуализации его разрушительных последствий, но ФЕ всё же несут негативную, пренебрежительную коннотацию. Как видится, в приведённых ситуациях ведущим фактором прагматического эффекта является невостребованность вымысла: реципиент либо находит его «некачественным» (скучным, глупым, слишком неправдоподобным и т.п.), либо просто не нуждается в нём, так как хочет знать истинное положение дел. В обоих случаях поведение субъекта вызывает чувства неодобрения, досады, раздражения.

(3) $О н$ вообщзе-то очень грамотный $и$ изепкий, я всегда внимательно слушаю, когда он всякие байки травит, массу полезньх вещей можно усльииать, которые потом в работе пригодятся [7, с. 82]; 
«Врешь! - подумал Иван Сергеевич. - Под чаек нам байки травишь! Но все равно слушать занятно и для дела полезно» [1, с. 306]. В этих ситуациях ясно прослеживается корреляция с концептом «Польза», что в значительной степени затушевывает негативную коннотацию ФЕ несмотря на сему пренебрежения и на квалификацию действия как дезинформации.

(4) По правилам игры можно рассказывать всё, кроме правды... Инспектор сочиняет, а секретариа знает, что он сочиняет. Однако такие мелочи не лишают никого удовольствия... [6, с. 64]; Он мастер травить байки. Легко и непринуждённо плетет истории... Причём все вокруг понимают, что он, мягко говоря, сочиняет, но делает это так увлекательно, что любо-дорого послушать [5, с. 327]. В этой группе контекстов актуализируется корреляция с концептами «Игра», «Удовольствие», «Искусство». Репрезентируется снисходительное и даже позитивное отношение к вымыслу, который забавляет и, собственно, никому не вредит. Более того, «высококачественный» вымысел ценится реципиентами, подобно тому как ценится произведение искусства. В таких контекстах часто используются позитивные оценочные лексемы (удовольствие, талант, увлекательно, мастер и т. п.), что усиливает позитивный прагматический эффект ФЕ. Заметим, что такая корреляция чаще и ярче всего объективируется в РЯ. Подобные ситуации, как представляется, выявляют характерную черту национального характера - любовь к «красивому» вымыслу и предпочтение его неприятной или прозаичной правде. Идея «эстетической» ценности вымысла и тенденция к восприятию его как средства скрашивания серой, обыденной реальности или избегания неприятной, болезненной правды объективируется также в АЯ, хотя и с гораздо меньшей частотностью: Hence the girl's story - half make-believe, half true... She put it in wrong way around, obeying her instinct to distort the truth by making it more dramatic [14, c. 207].

Следует отметить, что степень дискурсивной зависимости ФЕ с семантикой вымысла и влияние оценочной категоризации особенно высоки в РЯ. В качестве примера приведём два контекста, реализующих ФЕ сплести / придумать легенду: Красавища казачка посмотрела так, будто вывернула Мамонта наизнанку. - А зачем тебе она? Придумывать легенды не имело смысла, да и стылно было изворачиваться перед этими людьми [1, с. 185]. Здесь очевидна категоризация вымысла как дезинформации в логическом аспекте и 
как бесчестного поступка - в оценочном. Данная ситуация интересна эксплицированной негативной оценкой вымысла и в рациональнопрактическом (не имело смысла) и в эмоционально-нравственном плане (стылно). Лиля молча смотрела... и не задала ни одного вопроса. От этого мне стало неловко. Лучше бы она спросила, в чем дело, я бы ей сплел какую-нибудь легенду. А так она следила за мной своими темно-серыми глазищами, и мне казалось, что она все nонимает [7, с. 53]. В этом случае вымысел воспринимается как желанная возможность избавиться от психологического дискомфорта, сгладить ситуацию, мучительную для обоих участников. Происходит корреляция с концептами «Такт», «Милосердие». В результате негативная оценка практически сменяется положительной, а само действие вообще не квалифицируется как обман (хотя логически таковым является), поскольку категориальные признаки обмана теряют значимость и затушевываются.

Полагаем, что необходимо уделить внимание национальнокультурной специфике ФЕ, объективирующих вымысел. В рамках общей фразеосемантической модели в исследуемых языках наличествуют микромодели с образной основой, нацеленной на передачу дополнительных признаков и смыслов, не получивших специальной лингвистической реализации в других языках. Примерами таких специфических микромоделей могут служить ФЕ молоть вздор (РЯ), объективирующая глупые, пустые, абсурдные выдумки, и hard-luck story (АЯ), обозначающая вымышленную историю, рассказываемую с целью вызвать жалость, сочувствие реципиента и получить от этого выгоду. Данные ФЕ актуализируют, наряду с признаком очевидной ложности информации, дополнительные семы глупости (в РЯ), манипуляции и своекорыстия (в АЯ), определяющие иронично-пренебрежительную коннотацию и чувствоотношение неодобрения: ...а на самой опушке-то он и стоит! Утопленник. Стоит и кивает... - Клавдия Фемистоклюсовна, полно вздор молоть! - Какой еще вздор! Никакой не вздор! - Да вы же всё придумывваете! [10, с. 102-104]; Then he went round Mrs Emmon's shop and gave her a hard-luck story, and she gave him some quid [16, c. 329].

В целом анализ ФЕ с семантикой вымысла позволил выявить следующие межъязыковые закономерности: «прозрачность» вымысла как формы обмана, отражённая в компонентном составе ФЕ; общность структуры (одна основная фразеосемантическая модель со специфическими микромоделями внутри нее); общность образной 
категоризации для большинства составляющих; высокая степень флуктуации оценки и дискурсивной зависимости. Всё перечисленное обусловливает многоаспектность как оценочной, так и логической категоризации вымысла. Статус дезинформации в логическом аспекте и бесчестного поведения в оценочном вымыслу придают контексты, в которых реализуется комбинация семантических признаков ложности информации, осознанности, негативного целеполагания и вредоносных последствий. В оценочном плане вымысел воспринимается однозначно негативно, если реципиент хочет и считает себя вправе знать правду и видит в вымысле вред (корреляция с концептами «Опасность», «Разрушение» и т. п.), и снисходительно, если вымысел по-настоящему интересен и незауряден, забавен, безобиден или приносит пользу (корреляция с концептами «Игра», «Искусство», «Развлечение», «Польза»). Однако во многих случаях ведущим критерием оценочной категоризации становятся чисто ситуативные и индивидуально-личностные факторы - от специфики обстоятельств общения до сиюминутного настроения реципиента. Важной когнитивной межкультурной универсалией, отражённой ФЕ с семантикой вымысла, представляется также связь количества, частотности, семантической и эмоционально-оценочной градации его репрезентаций с эмоционально-ценностной потребностью, заинтересованностью носителей языка. Именно в этом аспекте прослеживается национально-культурная специфика отношения к вымыслу, проявляющаяся в степени указанной заинтересованности очень высокой у носителей РЯ и довольно низкой у носителей АЯ. Таким образом, исследованные нами ФЕ проявляют себя как эффективное средство экспликации универсальных и национальноспецифических черт восприятия феномена вымысла носителями русской и английской лингвокультур. Кроме того, их дальнейшее изучение в когнитивно-прагматическом аспекте может внести полезный вклад в понимание психологии обмана.

\section{Литература}

1. Алексеев С. Т. Сокровища Валькирии / С. Т. Алексеев. - М., 1995. - 432 с.

2. Баранов А. Н. Аспекты теории фразеологии / А. Н. Баранов, Д. О. Добровольский. - М. : Знак, 2008. - 656 с.

3. Вольф Е. М. Функциональная систематика оценки / Е. М. Вольф. - М. : Наука, 1985. $-271 \mathrm{c}$.

4. Ефремова Т. В. Новый словарь русского языка. Толковословообразовательный / Т. В. Ефремова. - М. : Русский язык, 2001. - 1232 с.

5. Квеселевич Д. И. Русско-английский фразеологический словарь / Д. И. Квеселевич. - М. : Русский язык, 1998. - 704 с. 
6. Леонов Н. И. Ловушка / Н. И. Леонов. - М. : ЭКСМО, 1995. - 464 с.

7. Маринина А. Б. Черный список: Роман, повесть / А. Б. Маринина. - М. : ЭКСМО, 1995. - $400 \mathrm{c}$.

8. Приходько Г. І. Способи вираження оцінки в сучасній англійській мові : [монографія] / Г. І. Приходько. - Запоріжжя : ЗДУ, 2001. - 362 с.

9. Третьякова И. Ю. Окказиональная фразеологія : [монографія]

И. Ю. Третьякова. - Кострома : КГУ им. Н. А. Некрасова, 2011. - 290 с.

10. Устинова Т. В. Закон обратного волшебства : Роман / Т. В. Устинова. - М. : Изд-во Эксмо, 2005. - 320 с.

11. Щербатых Ю. В. Искусство обмана. Популярная энциклопедия / Ю. В. Щербатых. - М. : Эксмо, 2007. - 720 с.

12. Boldyrev N. N. Evaluate Categorization / N. N. Boldyrev // Abstractsfrom Cognitive Linguistics East of Eden, September 13th-15th 2002. - Turku, 2002. - 52 p.

13. Chase J. H. The Vulture is a Patient Bird / J. H. Chase. - New York : Headline Books, 1989. - $341 \mathrm{p}$.

14. Christie A. Five Little Pigs / A. Christie. - N.Y : Berkley Books, 1984. - 216 p.

15. Ekman P. Lying and Deception / P. Ekman. - Mahwah, New Jersey : Lawrence Erlbaum Associates, 1997. - P. 333-347.

16. Longman Idioms Dictionary : over 6000 Idioms. - London : Pearson Education Limited, 1998. - 398 p.

17. Zinken J. Metaphors, Stereotypes and the Linguistic Picture of the World : Impulses from the Etnolinguistic School in Lublin / J. Zinken. - 2004. - Access : http://www.metaphorik.de. 